Marte Blikstad-Balas

Dr., Institutt for laererutdanning og skoleforskning, Universitet i Oslo

Tora Hфgenes

Master, Institutt for laererutdanning og skoleforskning, Universitetet i Oslo

\title{
Wikipedias inntog på kildelista - holdninger blant lærere og elever til Wikipedia i en skolekontekst
}

\section{Sammendrag}

I denne artikkelen diskuterer vi hvordan elever og laerere forholder seg til et av verdens mest populare nettsteder, det digitale leksikonet Wikipedia. Internasjonal forskning antyder at mens leksikonet er svart populart blant elever, kan mange larere styre sin begeistring for Wikipedia som faglig kilde $i$ skolearbeid. Studien vi presenterer kombinerer to ulike datakilder for å belyse empirisk hvordan elever og larere forholder seg til Wikipedia. Dataene om elevers holdninger er skriftlige svar 168 elever $i$ videregående skole har gitt på spфrsmål om hva de anser som de stфrste fordelene og de største ulempene med Wikipedia i skolesammenheng. Dataene som sier noe om hvordan larere forholder seg til det samme nettstedet er kvalitative intervjuer av fire samfunnsfaglarere. Larerne intervjues om hvordan de forholder seg til elevenes bruk av Wikipedia og $i$ hvilken grad de selv integrerer Wikipedia $i$ undervisningen sin. Studien viser at mens elevene er svart samstemte om Wikipedias kvaliteter, er det stor individuell variasjon i larernes holdninger til Wikipedia, og i hvorvidt de eksplisitt gir elevene opplaring og råd om kildekritikk. Vi finner også at flere elever anser laerernes skepsis som en av Wikipedias største ulemper $i$ skolesammenheng og tilpasser seg larernes preferanser på ulike vis. Avslutningsvis diskuterer vi implikasjoner av studien og argumenterer for at det kan vare uheldig om det er tilfeldig om Wikipedia adresseres eksplisitt $i$ undervisning eller ei.

\section{Introduksjon}

Det digitale leksikonet Wikipedia har i løpet av de siste ti årene etablert seg som et av verdens mest populære nettsteder - men det hersker stor uenighet om hvilken rolle Wikipedia bør ha $\mathrm{i}$ en utdanningskontekst. Mens mange er skeptiske til både innhold og bruk av Wikipedia i klasserommet, mener andre at nettstedet kan være en god faglig ressurs. Denne artikkelen handler om Wikipedias innpass i den norske skolen. Den norske konteksten er spesielt spennende fordi norske elever har en mye høyere tilgang til Internett både hjemme og i 
klasserommet enn det som er vanlig i en internasjonal kontekst, og Læreplanen for Kunnskapsløftet (LLK06) fremhever digital kompetanse som viktig og relevant i alle fag (Erstad, 2010). Det å jobbe med ulike typer tekst og ta i bruk varierte kilder fremheves også i planen. Med dette som utgangspunkt vil vi undersøke hvilke roller den mest populære digitale kilden blant elever og studenter, altså Wikipedia, får når den inngår i en skolekontekst. Det overordnede målet for artikkelen er å belyse hvilke holdninger et utvalg elever og lærere har til Wikipedia. Vi sikter også mot å belyse hvordan lærere og elever til tider forholder seg ulikt til den samme kilden og diskutere implikasjonene av dette.

Å undersøke hvordan Wikipedia inngår i klasserommets praksiser er viktig av flere grunner. For det første er det gjennomgående i både nasjonal og internasjonal forskning at Wikipedia er svært godt likt av elever, som opplever nettleksikonet som en relevant læringsressurs (Blikstad-Balas, 2013; Egeberg mfl., 2012; Raine \& Tancer, 2007; Rye \& Rye, 2011). Selv om dagens elever har den tekniske kompetansen som trengs for å gjøre informasjonssøk på Internett, er det imidlertid ikke gitt at de dermed også har den faglige og analytiske kompetansen som trengs for å kunne vurdere kildene de finner (Austvik \& Rye, 2011; Kiili mfl., 2008). Norske elever ser ut til å synes at kildekritikk er vanskelig, spesielt når det kommer til kildevurdering på nett (Frønes, Narvhus, \& Jetne, 2011). Her blir læreren viktig: Læreres oppfatning av ulike kilder har nemlig stor betydning for hvilke kilder elever bruker, og hvordan de bruker dem. Denne betydningen forsterkes når elevene jobber med nettbaserte læringsressurser, som for eksempel Wikipedia (Furberg \& Rasmussen, 2012). Samtidig som mange elever er positive til Wikipedia, er nettstedet omstridt. Vårt mål er derfor å undersøke hvordan Wikipedia inngår i en skolediskurs - fra både elevers og læreres ståsted.

Denne artikkelen kombinerer to ulike datakilder for å belyse empirisk hvordan elever og lærere forholder seg til Wikipedia. Dataene om elevers holdninger er skriftlige svar 168 elever i videregående skole har gitt på spørsmål om hva de anser som de største fordelene og de største ulempene med Wikipedia i skolesammenheng. Disse dataene er hentet inn av artikkelens førsteforfatter. Dataene om hvordan lærere forholder seg til det samme nettstedet, er hentet inn av annenforfatter, som har intervjuet fire samfunnsfaglærere om hvordan de forholder seg til elevenes bruk av Wikipedia og i hvilken grad de selv integrerer Wikipedia i undervisningen sin. Vi har altså innhentet empiri hos to ulike utvalg for å belyse det samme fenomenet, hvilket kan gi bedre forståelse av det vi undersøker enn hvert datasett alene (Creswell, 2014). Sammen gir disse dataene et innblikk ikke bare i hvordan elever og lærere ser på et av verdens mest bruke nettsteder, men også i komplekse overlappingspunkter - og motsetninger - i de utvalgte elevenes og lærernes holdninger til Wikipedia. 


\section{Teoretisk perspektiver: literacy som sosial praksis}

En helt sentral teoretisk orientering i denne artikkelen er den sosiokulturelle konteksten læring alltid er en del av. I det følgende vil vi introdusere kort noen sentrale teoretiske perspektiver innenfor literacy-feltet som er nært knyttet til nettopp dette sosiokulturelle synet på læring. Lesing og skriving er det mest grunnleggende formålet med all utdannelse, og som stadig flere vil vi benytte oss av begrepet literacy for å referere til lesing og skriving i bred forstand $\mathrm{i}$ en sosial kontekst. Vi vil bruke begrepet literacy uoversatt, hvilket er stadig vanligere (Skaftun, 2009; Skjelbred \& Veum, 2013).

I følge Sonia Livingstone (2009) kan begrepet literacy forstås både som individuelle ferdigheter og som sosial praksis. Både Joanne Larson og Jackie Marsh (2005) og David Barton (2007) påpeker at literacy tradisjonelt har blitt sett på som et sett lese- og skriveferdigheter som individet kunne lære uavhengig av kontekst og erfaring. Larson og Marsh (2005), Barton (2007) og Livingstone (2009) påpeker alle at det har blitt vanligere å erkjenne den sosiale kontekstens betydning for læring av slike ferdigheter. A forstå literacy som sosial praksis innebærer derfor å se at de individuelle lese- og skriveferdighetene alltid er formet av sosiale, kulturelle, økonomiske og politiske forhold. Livingstone (2009) argumenterer i tråd med dette for at literacy bør forstås som en kombinasjon av de to; individuelle lese- og skriveferdigheter som formes og påvirkes av samfunnet. I denne artikkelen bruker vi literacy-begrepet slik Livingstone (2009) gjør, hvilket innebærer å se lese- og skriveferdigheter i sammenheng med situasjonen de brukes i. Dette synet har sterk forankring i Kunnskapsløftet (Berge, 2005). Det viktigste poenget for oss ved å ta i bruk begrepet literacy, er å understreke at når en elev for eksempel velger å benytte seg av Wikipedia som utgangspunkt i sin skriving, så er ikke dette bare et individuelt valg. Dette valget vil alltid påvirkes av den sosiale konteksten. Literacy innenfor en skolediskurs blir ofte beskrevet som begrenset, fordi det ligger institusjonelle føringer og noen typer literacy foretrekkes fremfor andre (Barton, 2007; Gee, 2004; Street \& Lefstein, 2007). Det er vanlig innenfor literacy-forskning å operere med et skille mellom literacy som er sterkt forankret i institusjonelle rammer og mer eller mindre standardisert på den ene siden, og literacy som er selvvalgt, personlig og mer uformell på den andre siden (Barton, 2007; Freire \& Macedo, 1987; Gee, 2004; Street, 2003). For en problematisering av dette skillet, se Maybin (2007) og Blikstad-Balas (2012).

Det er funnet tydelige motsetninger i hvordan elever og lærere forholder seg til Wikipedia i skolehverdagen. Det er derfor naturlig å anta at det generelt vil være store forskjeller mellom hvordan Wikipedia inngår i elevers og læreres literacy-praksiser. Elever er gjerne begeistret for nettstedet, mens mange lærere både advarer mot og til dels også forbyr bruken av Wikipedia til skolearbeid (Austvik \& Rye 2011). Dette kan selvfølgelig være litt av et praktisk dilemma for elever, men de ulike holdningene til Wikipedia har også store implikasjoner 
for hva slags literacy-praksiser elevene møter $\mathrm{i}$ den formelle delen av skolegangen sin. Fordi literacy er en grunnleggende sosial praksis, utgjør det en vesensforskjell om elever overlates til mer eller mindre individuelle og personlige literacy-praksiser knyttet til valg av kilder, eller om de innlemmes i felles praksiser der både lærere og (med)elever kan gjøre sine kildevalg eksplisitte og begrunnede. Tilgang til Internett gjør at rammene for hva som til enhver tid «er» skolens literacy til en viss grad viskes ut, da elevene ikke lenger har tilgang kun til tekster skolen eller læreren har valgt for dem, men selv kan velge tekster (Blikstad-Balas, 2012). Disse perspektivene kommer vi tilbake til i diskusjonsdelen av artikkelen, hvor vi belyser nettopp hvordan Wikipedia påvirker skolens literacy-praksiser.

\section{Wikipedia i en skolekontekst- hva sier forskningen?}

Nettleksikonet Wikipedia, som ble lansert i 2001, er et uavhengig og gratis nettleksikon skapt og opprettholdt av frivillige bidragsytere (Lih, 2009). Wikipedia er til enhver tid en av verdens mest bes $\varnothing$ kte nettsteder, spesielt blant elever og studenter (Raine \& Tancer, 2007). Wikipedias popularitet er dessuten stadig økende (Zickuhr \& Raine, 2011). Til tross for denne enorme populariteten, er Wikipedia et kontroversielt tema innenfor den utdanningsvitenskapelige diskursen. Henk Eijkman (2010) hevder at kontroversen rundt Wikipedia primært er knyttet til tre forhold: selve innholdet, studenters (mis)bruk av informasjon funnet på Wikipedia og hvordan selve organiseringen av Wikipedia utfordrer etablerte måter å opprette og spre kunnskap på. Det er et motsetningsforhold mellom Wikipedias popularitet blant elever og studenter (Blikstad-Balas, 2013; Blikstad-Balas \& Hvistendahl, 2013; Lim, 2009; Raine \& Tancer, 2007) og nettstedets noe frynsete omdømme i akademia. Vi vil i det følgende komme inn på nettopp dette motsetningsforholdet i en forskningsgjennomgang der vi undersøker hvordan både elever og lærere forholder seg til Wikipedia i en skolekontekst.

Elever i dagens norske skole opplever Internett som en naturlig og integrert del av skolen, og de fleste vurderer nettbaserte læringsressurser som en naturlig del av læringsmiljøet (Rye \& Rye, 2011). Mange elever opplever også stor frihet til å velge hvordan de benytter Internettilgangen de har på skolen (BlikstadBalas, 2012; Elstad, 2006). Elevenes frihet kombinert med deres store tilgang på informasjon også utenfor klasserommets vegger, kan være i ferd med å endre det faktum at læreboka tradisjonelt har hatt et sterkt hegemoni i norske klasserom (Rambøll Managment, 2005; Skjelbred \& Aamotsbakken, 2010).

I artikkelen Ungdom, Internett og samfunnsengasjement (Rye \& Rye, 2011) presenteres funn fra en spørreundersøkelse gjennomført blant elever i videregående skole i Vest-Agder. Sentrale funn i vår sammenheng er at elevene har sterk motivasjon til å bruke Internett, og at Wikipedia vurderes som svært relevant i faget samfunnsfag, som studien begrenser seg til. Studien viser også at elevene synes Wikipedia er enkelt å bruke, faktisk rangeres Wikipedia som langt 
enklere å bruke enn for eksempel nettaviser og sosiale medier som Facebook. Det eneste nettstedet som oppleves som mer relevant enn Wikipedia av elevene i denne studien er Google - som ikke er en kilde, men kan gi deg forslag til kilder (Rye \& Rye, 2011). Her er det verdt å merke seg den nære sammenhengen mellom nettopp Wikipedia og Google. Dersom en elev velger å bruke Internett for å søke etter informasjon via en søkemotor, er nemlig sannsynligheten for å ende opp på Wikipedia svært høy. Dette henger sammen med at søkemotorer som Google bidrar direkte til Wikipedias popularitet, ved å plassere nettstedet høyt på listen over relevante søkeresultater. Forskning på ungdommers nettatferd (Shenton \& Dixon, 2004) antyder at mange elever benytter seg av ett søkeord, og at deres påfølgende handlinger vil være en direkte konsekvens av det søkemotoren rangerer som funn. Det er heller regelen enn unntaket at søkemotorens «svar» på elevens søkeord er nettopp Wikipedia.

Flere studier antyder at elever flest er nokså pragmatiske når de leter etter kilder, og nøyer seg med lett tilgjengelige kilder de anser som «gode nok» der og da. Denne tendensen er spesielt tydelig i Monitor 2011 (Egeberg mfl., 2012): Mange elever oppgir her at de foretrekker å bruke Wikipedia som kilde, til tross for at de samme elevene også oppgir at de har langt større tillit til digitale ressurser som nettsteder laget av etablerte forlag - som imidlertid er nettressursene de bruker minst. Sook Lims (2009) studie av amerikanske studenter viste at mange er villige til å velge rask og tilgjengelig informasjon, fremfor den mest troverdige informasjonen. Studentene i Lims utvalg antok ikke at de ville få den aller beste informasjonen om et emne ved å ta $\mathrm{i}$ bruk Wikipedia, men de vurderte informasjonen de fant i nettleksikonet som «god nok». Studien til Kaisa Leno (2006) viser at finske 15-åringer anser tilgang til informasjon som den største fordelen ved Internett, men at kun et fătall anser upålitelig eller irrelevant informasjon som en av Internetts ulemper. Carita Kiilli mfl. (2008) fant dessuten at finske videregåendeelever sjelden vurderer påliteligheten til informasjonen de finner, og at de i sterk grad bruker informasjon fra Wikipedia.

Anniken Furberg og Ingvill Rasmussen (2012, s. 25) viser at elever har en tendens til å være faktaorienterte fremfor forståelsesorienterte når de arbeider med nettbaserte kilder. De understreker at faktaorientering ikke er utelukkende negativt, da det er nødvendig å «(...) ha kjennskap til fakta om det som skal læres» samtidig som de viser til at elevtekster som produseres på grunnlag av nettbaserte kilder ofte inneholder mye gjengivelse av fakta og manglende forklaringer eller drøftinger. Ofte er elevene dessuten i en situasjon der de skal finne informasjon om noe de ikke kan så mye om fra før - hvilket gjør det vanskeligere å vurdere kritisk. Som Kiilli mfl. (2008) understreker, er elever tradisjonelt vant til å forholde seg til lærebøker og andre kilder fra lærere, med innhold som er vurdert som relevant og kvalitetssikret på forhånd. Forskningen vi har referert til fremhever ikke denne vesensforskjellen i kvalitetssikring 
mellom tradisjonelle kilder og digitale ressurser som noe elevene opplever som vesentlig.

Sammenlignet med hva vi vet om elever og Wikipedia i skolen, er det ikke mye vi vet om lærere på dette området. En relevant studie er Hilde Brox' (2012) pilot-spørreundersøkelse av norske lærerstudenters bruk av, forståelse for og holdninger til Wikipedia. 97\% av lærerstudentene som deltok i unders $\varnothing$ kelsen svarte at de selv brukte Wikipedia for å finne informasjon. Likevel avdekker undersøkelsen lav kunnskap blant de samme lærerstudentene om hvordan Wikipedia fungerer: $40 \%$ er ikke klar over at en kan endre det faglige innholdet. $28 \%$ tror bidragsytere må godkjennes av Wikipedia i forkant. 53\% tror at bidragsytere må skrive under fullt navn, og 79\% tror at bidragsytere må registrere seg før de kan publisere tekst (Brox, 2012). Alt dette er imidlertid feil. Utvalget i denne unders $\varnothing$ kelsen er ikke representativt for lærerstudenter i Norge, men den tegner likevel et interessant bilde av kommende norske læreres kunnskap - eller mangel på kunnskap - om Wikipedia.

Kristen Purcell mfl. (2013) har gjennomført en undersøkelse om hvordan amerikanske lærere bruker teknologi hjemme og i klasserommet. Spørreundersøkelse er brukt i kombinasjon med fokusgrupper bestående av lærere og elever. Et funn rapporten presenterer, er at læreres egen bruk av digitale verktøy kan stå i et motsetningsforhold til deres bekymringer for, og oppfatninger av, elevers bruk av de samme verktøyene (Purcell mfl., 2013). Andelen lærere som bruker Wikipedia er mye høyere enn andelen voksne, amerikanske internettbrukere som helhet: $87 \%$ mot 53\%. Samtidig frarådet lærerne ofte sine elever å bruke Wikipedia, på grunn av bekymring rundt innholdets troverdighet. I følge Purcell mfl. (2013) indikerer disse funnene at lærerne er bekymret for at elever ikke klarer å bruke Internett for å finne informasjon på en god måte, mens de altså har stor tro på egne ferdigheter på dette området.

Et annet relevant funn, som ikke handler om Wikipedia spesielt, men om digitale ferdigheter generelt, finner vi i rapporten Underveis, men i svært ulikt tempo (Ottesen \& Møller, 2010). I gjennomgangen av funn knyttet til implementeringen av de grunnleggende ferdighetene, beskriver Frøydis Hertzberg (2010) hvordan lærere og skoleledere fokuserer på utstyr og ressurser, ikke faktisk bruk, når det er snakk om hvordan digitale ferdigheter implementeres i praksis. Ofte er det lærernes kompetanse som trekkes frem fremfor elevenes. En konsekvens av dette er lite systematisk fokus blant lærere og skoleledere på pedagogisk bruk av slikt utstyr, og hva slik bruk kan bidra med i elevers læringssituasjon. 


\section{Metode og forskningsdesign}

Denne studien kombinerer to ulike datakilder for å belyse empirisk hvordan elever og lærere forholder seg til Wikipedia. Ved å innhente data hos to ulike utvalg for å belyse det samme fenomenet, sikter vi mot en bedre forståelse av det vi undersøker enn hvert datasett alene ville gitt (Creswell, 2014). Vårt mål med å kombinere ulike datakilder er ikke «to demonstrate that different data sources or inquiry approaches yield essentially the same result» (Patton, 1999, s. 1193), snarere er det å kunne se et fenomen belyst fra to ulike ståsteder. Hvordan norske elever forholder seg til Wikipedia finnes det en del forskning på (Blikstad-Balas, 2013; Blikstad-Balas \& Hvistendahl, 2013; Rye \& Rye 2011), men hva lærerne tenker om elevenes Wikipedia-vaner, er det færre som har undersøkt (Høgenes, 2013). I en skolekontekst er både lærere og elever helt sentrale aktører, og vi ser det derfor som nyttig å kombinere data om disse i én og samme studie. Sammen gir disse dataene et innblikk ikke bare i hvordan elever og lærere forholder seg til Wikipedia, men også i motsetninger og nyanser.

Dataene som utforsker elevenes holdninger til Wikipedia er korte tekster der elevene beskriver med egne ord hva de anser som de største fordelene og ulempene ved Wikipedia i en skolekontekst. Disse ble hentet inn som svar på åpne spørsmål i forbindelse med en kvantitativ digital spørreundersøkelse gjennomført med et utvalg på 168 elever fra åtte videregående skoler i Oslo og Akershus i 2012. Resultatene fra den kvantitative spørreunders $\varnothing$ kelsen knyttet til multiple-choice spørsmål er rapportert tidligere (Blikstad-Balas, 2013), men i denne studien har vi analysert hva elevene skriver med egne ord om hva de anser som Wikipedias fordeler og ulemper.

Dataene som utforsker læreres holdninger til Wikipedia er et resultat av kvalitative intervjuer, en metode som går igjen $\mathrm{i}$ et flertall av kvalitative forskningsartikler (Silverman, 2013). Grunnen til at intervju er valgt, er at det som unders $\emptyset$ kes ikke kan observeres direkte. Dessuten er det en styrke at intervju kan avdekke variasjoner i informantenes oppfatninger (Kvale \& Brinkmann, 2009). Fire lærere, som jobber på fire ulike videregående skoler i Oslo og Akershus, ble intervjuet enkeltvis i forbindelse med en studie om læreres forhold til Wikipedia i samfunnsfag (Høgenes, 2013). Lærerne ble intervjuet individuelt med den samme tematiske intervjuguiden som utgangspunkt, og intervjuene dreide seg om hvordan Wikipedia inngår i samfunnsfag. I denne studien vil vi analysere delene av intervjuene som direkte omhandler lærernes egne holdninger til Wikipedia og hvordan de forholder seg til elevenes bruk av nettstedet. 


\section{Analyse}

\section{Elever og Wikipedia}

Elevdataene vi presenterer ble kategorisert tematisk og analysert med det mål å identifisere fellestrekk i hva elevene anser som de fremste fordelene og ulempene ved å bruke Wikipedia i skolesammenheng. Vi vil bruke autentiske elevsvar for å underbygge den kvalitative analysen, og har gjennomgående valgt sitater som er så typiske som mulig, det vil si at de utrykker et meningsinnhold som er gjennomgående for mange av svarene i materialet. Der vi bruker sitater som er atypiske, er dette tydelig markert.

\section{Positive holdninger til Wikipedia - mange fordeler}

Et klart fellestrekk ved så å si samtlige av elevsvarene er at de uttrykker positive holdninger til Wikipedia. Dette samsvarer også med forskningslitteraturen vi har presentert i denne artikkelen. At elevene er positive til Wikipedia kommer klart frem, for eksempel beskriver en elev fordelene ved Wikipedia slik: «Lett tilgjengelig oppslagsverk i digital form, tilgjengelig på mange språk og jevnt over høy kvalitet på innholdet. Hva er det å ikke like?», mens andre beskriver Wikipedia som «[det er] en enkel søkemotor, som alltid har informasjon» og flere påpeker at Wikipedia er både «lett, enkelt, rent og relevant». Flere elever hevder at Wikipedia er bedre enn sitt rykte og «undervurdert». Beskrivelsene av fordeler ved Wikipedia er betydelig mer omfattende enn beskrivelsene de samme elevene gir av nettstedets ulemper, hvilket antyder en grunnleggende positiv holdning til Wikipedia.

De konkrete fordelene omtrent alle elevene nevner er at Wikipedia er enkelt, lett og oversiktlig. Dette henger sammen med både tilgjengelighet (hvor lett det er å lokalisere informasjonen) og hvordan informasjonen er skrevet. Mange elever skriver at det er «enkelt å finne informasjon», «enkelt å bruke», «lett å finne frem», «lett å søke», «lett å navigere» mens andre er opptatt av at Wikipedia er lett å lese: «(...)ofte lettere å forstå enn de lengre tekstene $\mathrm{i}$ lærebøkene», «enkelt, lett å forstå», «lett forståelig» og «lettlest informasjon». At det går fort å bruke Wikipedia, er en annen fordel det er stor enighet om. «Raskt», «kjapt» og «fort» er adjektiver vi finner gjennomgående i beskrivelsene av fordeler med Wikipedia.

Til tross for at samtlige elever som velger å sammenligne skolebøker og Wikipedia gjør dette på en måte nettleksikonet kommer mest heldig ut av, oppgir elevene ulike grunner til hvorfor de synes Wikipedia er bedre. På den ene siden fremhever flere elever at Wikipedia er lettere enn skolebøkene. Typiske begrunnelser for dette synet er at Wikipedia er «betydelig mer konkret og 'rett på sak' enn i læreboken», "Wikipedia gir et klarere svar på hva noe er, mens bøkene og andre artikler bruker lengre tid på å komme til et klart svar». Noen mener også at Wikipedia er «lettere å forstå enn lengre tekster i lærebøkene». Blant elevene som hevder Wikipedia er mer omfattende enn lærebøkene, er 
begrunnelsene forankret $\mathrm{i}$ at Wikipedia kan gi mer detaljert informasjon eller mer informasjon enn det de finner i skolebøkene. For eksempel skriver en elev at Wikipedia ofte «gir detaljert informasjon, noe boka ikke gjør da de prøver å forenkle», mens en annen fremhever at Wikipedia er «grei å bruke (...) hvis boka er mangelfull». Vi mener årsaken til at Wikipedia beskrives både som enklere og mer omfattende enn læreboka er at elevene selv kan velge hvor mye de vil fordype seg. Dersom man vil ha enkle, raske svar kan man finne det, er en derimot mer interessert i å gå i dybden og fordype seg i detaljer er det også en mulighet. Selv om elevene ikke sier dette eksplisitt, tolker vi disse funnene dithen at fleksibiliteten ved Wikipedia verdsettes av elevene.

Flere av elevene nevner at Wikipedia er spesielt godt egnet til å finne bakgrunnsinformasjon eller lese seg opp på et tema de ikke kan mye om fra før. For eksempel skriver elevene at Wikipedia er «en god side for å tilegne seg bakgrunnsinformasjon på», «det gir god oversikt i starten av et nytt tema» og at «hvis man blir presentert et helt nytt emne man ikke vet noe om, er Wikipedia en god side der man kan orientere seg om emnet». En elev skriver også at «selv om ikke alt er riktig får man i hvert fall det store bildet». Pragmatikken som antydes i dette utsagnet, altså at informasjonen er verdt å bruke til tross for at den kan være unøyaktig, er gjennomgående i flere av elevsvarene.

\section{Ulemper ved Wikipedia: potensiell feilinformasjon og lærerskepsis}

Når det gjelder ulemper, er elevene samstemte: at informasjonen kan være feilaktig er det enighet om. Likevel er det noen spennende nyanser i elevenes beskrivelser. Noen elever mener at feilinformasjon i seg selv er et problem: «Informasjon på Wikipedia kan være feil», at Wikipedia «ikke er til å stole på», og at det kan være vanskelig å vurdere hva som er pålitelig og hva som er unøyaktig. Til tross for at elevene er klar over at informasjonen kan være mangelfull, er det flere som utrykker lærerens skepsis som den aller største ulempen: «lærere er ikke fornøyd med det som kilder», «det er en useriøs kilde for lærere og professorer (...)», «lærere er ofte negative til Wikipedia som kilde» og «ikke godkjent av lærere» er noen eksempler på slike svar, flere elever har faktisk listet dette som den eneste ulempen ved Wikipedia i skolesammenheng. Det kan altså virke som flere elever i realiteten ikke frykter å få upålitelig informasjon, men snarere frykter kritikk for kildevalget sitt. Dette dilemmaet er det flere som viser frustrasjon over, én elev skriver til og med «læreren synes det er en dårlig kilde fordi det er skrevet av hvem som helst, men da synes jeg de skal komme med en like enkel kilde å forstå som Wikipedia er». Elevbeskrivelsene av fordeler og ulemper med Wikipedia forteller oss altså flere ting: elevene gir uttrykk for at de verdsetter Wikipedia høyt og at de anser det som et enkelt, raskt og nyttig nettsted som de gjerne benytter seg av, spesielt dersom de vil ha en rask oversikt over et nytt emne. Om ulemper skriver elevene mindre, men det er stor enighet om at potensiell feilinformasjon og manglende pålitelighet er en betydelig ulempe. For flere er imidlertid lærernes skepsis til 
Wikipedia det aller største problemet. Nettopp hvordan et utvalg lærere ser på Wikipedia, er fokus i neste analyse.

\section{Lærere og Wikipedia}

Det empiriske grunnlaget for den følgende analysen av læreres holdninger til nettleksikonet, er hentet fra deler av lærerintervjuene som omhandler lærernes holdninger knyttet til elevenes bruk av Wikipedia. Vi har valgt å kalle lærerne Ola, Trine, Pål og Lars. De uttrykker både at de opplever stor metodefrihet og selv kan avgjøre hvordan de forholder seg til Wikipedia i sine fag, og at de opplever at elevene i utstrakt grad benytter seg av nettstedet. For eksempel forteller Trine at hun sjelden har hatt en presentasjon, verken muntlig eller skriftlig, som ikke inkluderer Wikipedia som kilde. Også Ola sier han har et inntrykk av at Wikipedia «veldig ofte står oppgitt» når elevene blir bedt om å oppgi kilder. Pål og Lars bekrefter også at deres elever bruker leksikonet mye og ofte. Som vi skal se i det følgende, har disse lærerne ulike praksiser når det gjelder å forholde seg til at elevene deres er aktive Wikipedia-brukere.

\section{Lærerskepsis til Wikipedia?}

Som vi så i analysen av elevers holdninger til Wikipedia, kom det tydelig frem at flere elever synes læreres antatte skepsis er den største ulempen ved Wikipedia. En slik skepsis blir gjort eksplisitt i lærerintervjuene. For eksempel forteller Ola følgende:

Intervjuer: Når det gjelder Wikipedia. Er dette noe du bruker selv?

Ola: $\quad$ Aldri.

Intervjuer: Nei?

Ola: $\quad$ Nei, så og si aldri bruker jeg det selv og jeg oppfordrer vel aldri elevene til å bruke det heller.

Intervjuer: Nei?

Ola: $\quad$ Svært sjelden.

Intervjuer: Hvorfor det?

Ola: Jeg er vel gammeldags da... Har litt fordommer mot det.

Mens Ola altså sier at hans manglende bruk skyldes fordommer og at han er gammeldags, sier Trine eksplisitt at hun ikke stoler helt på Wikipedia:

Trine: $\quad$ Det bruker å være for overfladisk, og så er det vel også fordi jeg ikke hundre prosent stoler på Wikipedia som kilde (...) Jeg har hørt rykter om at på Wikipedia går det an ... At det er veldig mange som kan gå inn og legge inn stoff der.

Pål sier at han pleier å si til elevene at «Internett er veldig bra, men $80-90 \%$ er bare tøv», og er opptatt av at elevene må være mer opptatt av kvalitetssikringen 
nettsteder har eller ikke har. Når det gjelder Wikipedia spesielt, pleier han å komme med eksempler på ting som har vært feil i leksikonet (for eksempel om tidligere statsminister Jens Stoltenberg, et eksempel vi kommer tilbake til), og si til elevene at:

Pål: $\quad(\ldots)$ at det [Wikipedia] er veldig bra, det har vært verre, men det er fremdeles plaget av mye rart.

Lars er den av lærerne som er mest positiv til Wikipedia. Han forteller at han ser på det som en utfordring at det ikke er noe redaktøransvar, men at dette bare betyr at det er opp til leseren å vurdere troverdigheten av det han eller hun leser:

Lars: $\quad$ (...) fordi utfordringen er jo at det er jo ikke noe redaktøransvar på Wikipedia, Men det betyr jo ikke at den enkelte artikkel - at det ikke er kvalitetsforskjell mellom de enkelte artiklene, men det er da mer i større grad opp til oss å finne ut av.

\section{Wikipedia i undervisningen}

Til tross for at de fire lærerne deler oppfatningen om at Wikipedia er mye brukt av deres elever, integrerer de Wikipedia i undervisningen i ulik grad. Under intervjuet ble lærerne bedt om å utdype i hvilken grad de snakker om Wikipedia med elevene sine, eller på andre måter gjør Wikipedia til en del av undervisningen.

Ola forteller at han ikke bruker Wikipedia mye i timene, til tross for at han mener elevene hans liker «å ty til det». Han svarer følgende på spørsmålet om hvorvidt han har snakket om Wikipedia med elevene sine:

Ola: Kanskje nevnt noe om at jeg ønsker de skal bruke andre kilder, men vi har ikke brukt mye tid på det, det kan jeg ikke si.

Intervjuer: Nei?

Ola: Ikke på Wikipedia, nei. Jeg har ikke nevnt det spesifikt eller satt av tid til det, nei.

Påls praksis ser ut til å ligne Olas, da han også forklarer at han i starten av skoleåret ofte minner elevene om at Wikipedia er en kilde med «veldig ulik kvalitet» som de selv må etterprøve.

Trine mener Wikipedia kan være et godt utgangspunkt for å jobbe med nytt stoff eller oppklare begreper, og til tider oppfordrer hun elevene til å bruke nettleksikonet. Hun sier hun ikke har brukt nok tid på å snakke om kilder med elevene sine og forteller at hun fremover kommer til å legge mer vekt på å undervise i kildekritikk. Dette begrunner hun med at hun «opplever at elevene er så glade i Wikipedia». 
Det er kun Lars som sier han inkluderer Wikipedia i lærerstyrt undervisning. Han gir et eksempel på hvordan dette kan foregå:

Lars: $\quad$ (...) Det kan være at vi for eksempel ser på Wikipedia-artikler sammen og så ser vi på hva slags kilder den artikkelen bygger på, og så sammenligner vi kanskje med Store Norske Leksikon, som vi har tilgang til ved skolen.

\section{Wikipedia sammenlignet med andre kilder}

Alle lærerne kommer inn på kilder de gjerne vil at elevene skal bruke. Læreboka beskrives som viktig av flere, men digitale kilder som aviser, nettsidene til statistisk sentralbyrå og NRKs nyhetssider nevnes også av lærerne som sentrale $\mathrm{i}$ samfunnsfag. Pål, Lars og Trine sammenligner raskt Wikipedia med den digitale versjonen av Store Norske Leksikon (SNL), som de verdsetter på grunn av redaktøransvaret. Pål beskriver SNL som en mer korrekt kilde enn Wikipedia, og omtaler SNL som et «sted der man er nøye», i klar motsetning til Wikipedia. Han kommer med et eksempel for å illustrere poenget sitt:

Pål: $\quad$ Som for eksempel at Jens Stoltenberg for et par år siden ble beskrevet som en av de mest kjente halliker i Oslo på Wikipedia. Sånt skjer ikke på SNL, på steder der man er nøye. Men om man får hele folket til å skrive, så blir det fort sånn at det finnes råtne epler i kurven.

Trine kommer også inn på at redaktøransvar er noe som øker troverdigheten til en kilde:

Trine: Jeg tenker at den [SNL] er mer troverdig, fordi der sitter det en som gir det ut og må stå ansvarlig for fagstoffet.

Lærerne kommer inn på at elevene gjerne velger andre kilder enn de selv helst ville ha sett $\mathrm{i}$ bruk og at de til tider lar seg frustrere av elevenes kildevalg. Pål får spørsmål om hvordan elevene hans er når det gjelder kildekritikk:

Pål: $\quad$ Den er veldig variert, fordi det har å gjøre med deres fortid, i ungdomsskolen. Noen, et fåtall, har litt tanker om det, de fleste er helt bevisstløse.

Intervjuer: Ja?

Pål: $\quad$ Ja. Det må jeg si. Helt bevisstløse.

At elevene tilpasser seg lærernes ønsker, er noe vi kommer inn på flere ganger i intervjuene. Et spennende moment er at lærerne nevner at elevene ofte fors $\varnothing$ ker å gi inntrykk av å ha brukt flere kilder enn de i realiteten har brukt, for å 
tilfredsstille lærerne sine. Trine forteller at elevene har lært seg å ta avstand fra Wikipedia:

Trine: $\quad$ Og i de senere åra, det opplevde jeg ikke før, de senere åra merker jeg at elever sier «også har vi brukt Wikipedia, ja, den er jo ikke helt... troverdig, da, så vi har også brukt andre kilder for å støtte at det vi fant på Wikipedia er riktig»,

Intervjuer: Ja?

Trine: $\quad$ Nå opplever jeg ofte at det ikke er sant at de gjør det, men de har lært seg til å si at Wikipedia ikke er helt troverdig. Så klarer jeg ofte ikke helt å se at de virkelig har brukt andre kilder som kunne støtte det de sa.

Ola betviler også at alle kildene på litteraturlista til elevene faktisk er tatt i bruk:

Ola: Det generelle inntrykket er at de limer på noen kilder til slutt.For det må de ha. Og så... dessverre tror jeg ikke alle er like bevisste, jeg tror ikke det er sånn at de har sittet med trefire kilder og vurdert hvilke som skal brukes. Det tviler jeg på. For det er vanskelig. Jeg tror det er en vanskelig jobb for VG1elever. Så inntrykket er kanskje at de limer på et par ekstra til slutt for at det skal se bedre ut rett og slett. Det kan være tilfellet.

Intervjuer: Når du bruker uttrykket «lime på», mener du da at dette er noe de gjør for at læreren skal bli fornøyd?

Ola: Ja.

\section{Diskusjon}

Målet med denne artikkelen er å belyse Wikipedias rolle i skolen, med utgangspunkt i hvilke holdninger lærere og elever har til nettstedet. Vi vil i det følgende diskutere nærmere implikasjonene av studiens viktigste funn.

For det første er det verdt å merke seg hvor positive mange av elevene er til Wikipedia. Dette går også igjen i forskningslitteraturen vi har gjengitt, og lærerne som er intervjuet bekrefter at elevene deres svært ofte bruker nettopp Wikipedia. At Wikipedia spiller en så stor rolle i elevenes literacy-praksiser, begrunner de med at nettstedet er raskt og enkelt. Det er altså tilgjengeligheten som regnes som den fremste fordelen, mens varierende kvalitet på innhold eller læreres fokus på den varierende kvaliteten - oppgis som de største ulempene. Som Austvik og Rye (2011) påpeker, kan elevers måte å forholde seg til Wikipedia på antyde en instrumentell forståelse av oppgaver de skal gjøre. Informasjonss $\emptyset \mathrm{k}$ blir ofte redusert til et spørsmål om å skaffe "riktig" 
informasjon. Det er påfallende at elevene som er så positive til Wikipedia i så liten grad er opptatt av kvaliteten på informasjonen. Dette kan igjen antyde at elevenes literacy-praksiser der Wikipedia inngår, er relativt snevre praksiser der Wikipedia oppfattes som den raskeste leverandøren av "god nok" informasjon. Elevene gir nemlig uttrykk både for at de ikke anser Wikipedia som den aller beste informasjonen kvalitetsmessig og at lærere gjerne misliker Wikipedia som kilde. Likevel er det nettopp Wikipedia de selv helst benytter seg av. At elevene er opptatt av praktiske hensyn fremfor kvalitetsvurderinger av innhold, er en tendens som går igjen i andre studier (Austvik \& Rye, 2011; Egeberg mfl., 2012; Lim, 2009). Det antyder at det fremdeles oppfattes som en relevant praksis i skolen å kunne gi svar på deskriptive faktaorienterte oppgaver (Scardamalia \& Bereiter, 2006), og at Wikipedias popularitet blant elevene skyldes evnen til å skaffe raske svar. Hvis vi ønsker at elevene skal gjøre noe annet enn å reprodusere mengder av lett tilgjengelige fakta, må vi gi oppgaver som krever noe annet enn nettopp dette.

For det andre mener vi lærernes ulike Wikipedia-praksiser er et vesentlig funn. Tre av lærerne i utvalget nøyer seg med å si at de helst ikke vil at elevene skal bruke nettleksikonet, uten å oppgi grunn, mens én lærer ofte inkluderer Wikipedia i undervisningen. Dette kan tyde på at det er relativt tilfeldig og læreravhengig i hvilken grad Wikipedia blir integrert i skolens offisielle og intenderte praksiser. Siden det er opp til lærerne selv om de velger å inkludere Wikipedia i undervisningen eller ei, så er det naturlig nok ikke alle lærere som gjør det. Denne tilsynelatende tilfeldige praksisen, kombinert med elevenes positive holdninger til og utstrakte bruk av Wikipedia, betyr at det vil variere fra lærer til lærer i hvilken grad Wikipedia ikke bare er en del av elevenes personlige literacy-praksiser, men forankres i skolens offisielle diskurs.

At det er spenninger mellom lærernes praksiser, elevenes intenderte praksiser og elevenes reelle praksiser har vi vist flere eksempler på i dette materialet. Tydeligst ser vi dette når elever tilpasser seg lærernes ønsker om å bruke flere kilder ved å liste opp referanser de kanskje aldri har brukt. Her ser vi tydelig spenningen mellom elevers og læreres holdninger til Wikipedia, og at elevene tilpasser sine personlige praksiser til literacy forankret i skolediskursen. Vi mener det er betimelig å stille spørsmål om hvorvidt lærerne først og fremst er kritiske til Wikipedia, eller om det snarere dreier seg om at de er kritiske til de faktaorienterte praksisene som er nært knyttet til nettleksikonet. At elever er opptatt av å løse oppgaver raskt ved å skaffe «kjappe fakta» er langt i fra et nytt fenomen.

Det at Wikipedia fremstår som en helt sentral læringsressurs for elevene, er i seg selv en god grunn til at lærere også burde forholde seg aktivt til nettstedet. Alle literacy-praksiser har grunnlag i en eller flere tekster, i vid forstand. Både denne og andre unders $\varnothing$ kelser viser at Wikipedia spiller en sentral rolle i mange elevers literacy-praksiser. Flere elever etterlyser også bedre forklaringer eller uttrykker frustrasjon over lærerens manglende aksept for Wikipedia. Samtidig 
sier kun én av lærerne som er intervjuet i forbindelse med denne studien, at han velger å inkludere Wikipedia eksplisitt i undervisningen. Lærerne og elevene har altså ofte ulike holdninger til Wikipedia, men fordi lærerne er de som har mulighet til å definere hvilke tekster som regnes som aksepterte kilder i faget, preger dette også elevenes literacy-praksiser. Dette er flere av lærerne i dette materialet inne på, da de fremhever at elevene tilpasser sine praksiser til lærernes krav. Dette er funnet også i andre undersøkelser, se for eksempel Blikstad-Balas og Hvistendahl (2013).

Vi mener det viktigste bidraget $\mathrm{i}$ forskningen vi har presentert $\mathrm{i}$ denne artikkelen, er synliggjøringen av avstanden i holdningene elever og lærere har til den samme faglige kilden, altså Wikipedia. Det er et vesentlig funn at flere elever anser lærernes skepsis som en av Wikipedias største ulemper i skolesammenheng og tilpasser seg lærernes preferanser på ulike vis. Dette er et felt der det er gjort lite forskning, og det er viktig at Wikipedias rolle i skolen utforskes nærmere. En begrensning ved dette materialet er at vi har intervjuet få lærere, og at lærerdataene ikke kan kobles direkte til elevdataene. Siden vi kun har intervjuet fire lærere, kan det knapt hevdes at lærerdataene er generaliserbare. Likevel mener vi altså at dataene vi presenterer belyser noen viktige problemstillinger, og at det er viktig at både lærere og elevers praksiser blir gjenstand for videre forskning. Spesielt synes vi det er behov for større undersøkelser av hvordan læreres forhold til Wikipedia påvirker elevenes bruk og hvordan Wikipedia brukes sammen med andre kilder, som for eksempel Store Norske Leksikon. Vi mener også det er behov for at vellykkede case der Wikipedia inkluderes i ulike fag -på fagenes premisser - må løftes frem.

Sist, men ikke minst, er det viktig å huske at Wikipedia kun er ett alternativ for informasjon. Riktignok er det et stort, omfattende leksikon, men en stadig viktigere del av literacy-kompetanse går ut på å vurdere ulike kilder og å kunne velge hva som passer best til ulike formål. Det fordrer at skolen klarer å gjøre en rekke relevante kildekritiske literacy-praksiser tilgjengelig for elevene sine. Slik denne undersøkelsen antyder, vil det i dag kunne variere sterkt i hvilken grad dette gjøres i ulike klasserom.

\section{Referanser}

Austvik, J. \& Rye, S. A. (2011). Digitale medier, samfunnsfag og samfunnsengasjement. Skriftserien. Universitetet i Agder. Hentet fra http://brage.bibsys.no/hia/handle/URN:NBN:no-bibsys_brage_16523

Barton, D. (2007). Literacy: an introduction to the ecology of written language. Malden, Mass.: Blackwell Pub.

Berge, K. L. (2005). Skriving som grunnleggende ferdighet og som nasjonal prøve - ideologi og strategier. In A. J. Aasen \& S. Nome (Red.), Det Nye norskfaget. Bergen: Fagbokforlaget. Hentet fra http://folk.uio.no/kjellbe/Skriving.pdf

Blikstad-Balas, M. (2012). Digital literacy in upper secondary school: What do students use their laptops for during teacher instruction. Nordic Journal of Digital Literacy, 7(2), s. 81-96. 
Blikstad-Balas, M. (2013). Et svar på nesten alt - om elevers bruk av Wikipedia som faglig kilde i videregående skole. Norskloereren, 13, s. 34-43.

Blikstad-Balas, M. \& Hvistendahl, R. (2013). Students' digital strategies and shortcuts Searching for answers on Wikipedia as a core literacy practice in upper secondary school. Nordic Journal of Digital Literacy, vol. 8 (1-2). s. 32-48.

Brox, H. (2012). The elephant in the room: A place for Wikipedia in higher education? Norlit, 20, s. 143-155. URL: http://septentrio.uit.no/index.php/nordlit/article/viewFile/2377/2195

Creswell, J. W. (2014). Research design : qualitative, quantitative, and mixed methods approaches (4.utg.). Los Angeles, California: Sage.

Egeberg, G., Gudmundsdottir, G. B., Hatlevik, O. E., Ottestad, G., Høie Skaug, J., \& Tømte, K. (2012). Monitor 2011. Skolens digitale tilstand.Oslo. Senter for IKT i utdanningen.

Eijkman, H. (2010). Academics and Wikipedia: Reframing Web 2.0+ as a disruptor of traditional academic power-knowledge arrangements. Campus-Wide Information Systems, 27(3), s.173-185.

Elstad, E. (2006). Understanding the nature of accountability failure in a technology-filled, laissez-faire classroom: disaffected students and teachers who give in. Journal of Curriculum Studies, 38(4), s. 459-481.

Erstad, O. (2010). Digital kompetanse i skolen (2. utg.). Oslo: Universitetsforlaget.

Freire, P., \& Macedo, D. (1987). Literacy: reading the word \& the world. London: Routledge.

Frønes, T. S., Narvhus, E. K., \& Jetne, Ø. (2011). Kortrapport. Elever på nett. Digital lesing $i$ PISA 2009. Oslo. Universitetet i Oslo

Furberg, A., \& Rasmussen, I. (2012). Faktaorientering og forståelsesorientering i elevers bruk av nettbaserte læringsomgivelser. T. E. Hauge \& A. Lund (Red.), Små skritt eller store sprang? Om digitale tilstander i skolen. Oslo: Cappelen Damm Akademisk.

Gee, J. P. (2004). Situated language and learning: a critique of traditional schooling. London: Routledge.

Hertzberg, F. (2010). Arbeid med grunnleggende ferdigheter. E. Ottesen \& J. Møller (Red.), Underveis, men i svoert ulikt tempo. Et blikk inn i ti skoler etter tre år med Kunnskapsløftet.Delrapport 3 Underveisanalyse av Kunnskapsløftet som styringsform (s. 77-89): NIFU STEP. URL: http://www.udir.no/Upload/Rapporter/2011/5/fire tredje.pdf

Høgenes, T. (2013). Lærere og Wikipedia: fire læreres forhold til Wikipedia som kilde i samfunnsfag. Masteravhandling. Institutt for lærerutdanning og skoleforskning, Universitetet i Oslo. URL: https://www.duo.uio.no/handle/10852/37798

Kiili, C., Laurinen, L., \& Marttunen, M. (2008). Students evaluating internet sources: From versatile evaluators to uncritical readers. Journal of Educational Computing Research, $39(1)$, s, 75-95.

Kvale, S., \& Brinkmann, S. (2009). Interviews: learning the craft of qualitative research interviewing (2.utg.). Los Angeles, California: Sage.

Larson, J., \& Marsh, J. (2005). Making literacy real: theories and practices for learning and teaching. London: Sage.

Leno, K. (2006). Reading the Web-Students' perceptions about the Internet. Scandinavian Journal of Educational Research, 50(5), s.541-557.

Lih, A. (2009). The Wikipedia revolution: how a bunch of nobodies created the world's greatest encyclopedia. London: Aurum.

Lim, S. (2009). How and why do college students use Wikipedia? Journal of the American Society for Information Science and Technology, 60(11), s.2189-2212.

Livingstone, S. M. (2009). Children and the internet: great expectations, challenging realities. Cambridge: Polity.

Maybin, J. (2007). Literacy under and over the desk: Oppositions and heterogeneity. Language and Education, 21(6), s.515-530. 
Ottesen, E. \& Møller, J. (2010). Underveis, men i svcert ulikt tempo: et blikk inn i ti skoler etter tre år med Kunnskapsløftet. Delrapport 3 Underveisanalyse av Kunnskapsløftet som styringsform. Oslo: NIFU STEP. Hentet fra http://www.udir.no/Upload/Rapporter/2011/5/fire tredje.pdf

Patton, M. Q. (1999). Enhancing the quality and credibility of qualitative analysis. Health services research, 34(5 Pt 2), s.1189-1208.

Purcell, K., Heaps, A., Buchanan, J. \& Friedrich, L. (2013). How Teachers Are using Technology at Home and in Their Classrooms. Hentet fra http://www.pewinternet.org/ /media//Files/Reports/2013/PIP TeachersandTechnologywit hmethodology PDF.pdf: Pew Research Center.

Raine, L. \& Tancer, B. (2007). Wikipedia users. Washington, DC: Pew Internet \& American Life Project, hentet fra http://pewinternet.org/Reports/2007/Wikipedia-users.aspx.

Rambøll Managment. (2005). Kartlegging av loeremidler og loeremiddelpraksis. Rapport til Utdanningsdirektoratet. København.

Rye, S. A. \& Rye, J. F. (2011). Ungdom, Internett og samfunnsengasjement. Tidsskrift for ungdomsforskning, 11(2), s. 25-47.

Scardamalia, M. \& Bereiter, C. (2006). Knowledge building: Theory, pedagogy, and technology. R. K. Sawyer (Red.), The Cambridge handbook of the learning sciences (s. 97-115). Cambridge: Cambridge University Press.

Shenton, A. K. \& Dixon, P. (2004). Issues arising from youngsters' information-seeking behavior. Library \& Information Science Research, 26(2), s. 177 -200.

Silverman, D. (2013). Doing qualitative research : a practical handbook (4.utg.). Los Angeles, California: Sage.

Skaftun, A. (2009). Litteraturens nytteverdi. Bergen: Fagbokforlaget.

Skjelbred, D. \& Aamotsbakken, B. (2010). Lesing av fagtekster som grunnleggende ferdighet. Oslo: Novus.

Skjelbred, D. \& Veum, A. (2013). Literacy i loeringskontekster.Oslo:Cappelen Damm Akademisk

Street, B. (2003). What's "new" in New Literacy Studies? Critical approaches to literacy in theory and practice. Current Issues in Comparative Education, 5(2). s. 77-91.

Street, B. V. \& Lefstein, A. (2007). Literacy : an advanced resource book. London: Routledge.

Zickuhr, K. \& Raine, L. (2011). Wikipedia, past and present. Pew Research Center's Internet $\&$ American Life Project, hentet fra http://pewinternet.org/ /media/Files/Reports/2011/PIP Wikipedia., 